\title{
Estimation of Mean Performance in Sorghum Downy Mildew Resistant Back Cross Progenies $\left(\mathrm{BC}_{3} \mathrm{~F}_{1}\right)$ of Maize
}

\author{
K. Sumathi ${ }^{1 *}$, K.N. Ganesan ${ }^{2}$ and N. Senthil ${ }^{3}$ \\ ${ }^{1}$ Centre for Plant breeding and Genetics, TNAU Coimbatore, India \\ ${ }^{2}$ Agriculture Research Station, Bhhavanisagar, TNAU Coimbatore, India \\ ${ }^{3}$ Department of Biotechnolog, AC \& RI, Madurai, TNAU Coimbatore, India \\ *Corresponding author
}

\begin{tabular}{l} 
Ke y w o r d s \\
Variability analysis, \\
Sorghum Downy \\
Mildew resistant \\
back cross \\
progenies, Maize \\
Article Info \\
$\begin{array}{l}\text { Accepted: } \\
\text { 25 May } 2018 \\
\text { Available Online: } \\
\text { 10 June } 2018\end{array}$ \\
\hline
\end{tabular}

\section{A B S T R A C T}

The present investigation was carried out at Department of Millets, Centre for Plant Breeding and Genetics, Tamil Nadu Agricultural University, Coimbatore, Tamil Nadu, India to identify the best performing Sorghum Downy Mildew resistant progeny for agronomical traits. The objective of this study was to identify the better per se performance of the resistant progeny. Twelve biometrical characters of sixteen SDM resistant progenies viz., UMI 79/936-C1-3-2, UMI 79/936-C1-3-4, UMI 79/936-C1-7-2, UMI 79/936-C1-29-8, UMI 79/936-C1-29-9, UMI 79/936-C1-29-13, UMI 79/936-C1-2923, UMI 79/936-C1-29-35, UMI 79/936-C1-29-36, UMI 79/936-C1-67-3, UMI 79/936C1-67-12, UMI 79/936-C1-67-25, UMI 79/936-C1-101-12, UMI 79/936-C1-101-13 and UMI 79/936-C1-101-14 were used for mean performance. Studies revealed that among the progenies, UMI 79/936-C1-7-7-7 and UMI 79/936-C1-7-7-2 showed better per se performance for yield contributing characters. These two progenies showed highest mean values than the other progenies. It exhibited more mean values than the parents for the characters viz., Cob length, Cob diameter, No.of rows per cob, No.of. Kernels per row, Cob weight, Yield per plant, 100 grain weight. Based on the mean values progenies UMI 79/936-C1-7-7-7 and UMI 79/936-C1-7-7-2 confirmed as the best progenies.

\section{Introduction}

Maize (Zea mays L.) is world's third most important crop after rice and wheat. It is a versatile crop, growing across a range of agro ecological zones. The importance of maize to sustainable development cannot be overstated. Maize is utilized as food for human consumption, as feed for livestock and as a raw material for industry (FAO, 1992). Plant breeders are interested in developing cultivars resistant to pest and disease with improved yield and other phenological characters. In order to achieve this goal, the breeders had the option of selecting desirable genotype in early generations or delaying intense selection until advanced generations. Downy mildews are important maize diseases in many tropical regions of the world. They are particularly destructive in many regions of tropical Asia where losses in excess of $70 \%$ have been documented. Globally, downy mildew 
affected areas with significant economic losses are reported to be as high as $30 \%$ (Jeffers et al., 2000).

Mean is the primary criterion for selection in any breeding programme. Mean serves as a basis for eliminating undesirable crosses or progenies. Hence, the present studies were undertaken to identify the best performing SDM resistant progeny for yield contributing characters through mean performance.

\section{Materials and Methods}

The experiments were conducted at Department of Millets, Centre for Plant Breeding and Genetics, Tamil Nadu Agricultural University, Coimbatore, Tamil Nadu, India during Rabi2013. $\mathrm{BC}_{3} \mathrm{~F}_{1}$ population was used in the present study. It is derived from crossing the inbred UMI 79 which is susceptible for sorghum downy mildew and UMI 936(w) which has resistance for sorghum downy mildew and backcrossing progenies with UMI79. Sixteen progenies viz., viz., UMI 79/936-C1-3-2, UMI 79/936-C1-34, UMI 79/936-C1-7-2, UMI 79/936-C1-29-8, UMI 79/936-C1-29-9, UMI 79/936-C1-29-13, UMI 79/936-C1-29-23, UMI 79/936-C1-2935, UMI 79/936-C1-29-36, UMI 79/936-C167-3, UMI 79/936-C1-67-12, UMI 79/936-C167-25, UMI 79/936-C1-101-12, UMI 79/936C1-101-13 and UMI 79/936-C1-101-14UMI 79/936-C1-3, UMI 79/936-C1-7, UMI 79/936C1-29, UMI 79/936-C1-67, and UMI 79/936C1-101 were confirmed as resistant to sorghum downy mildew under sick plot condition.

In these sixteen progenies the data on twelve quantitative characters viz., days to $50 \%$ tasseling, days to $50 \%$ silking, plant height, Ear height, Cob length, Cob diameter, Number of rows per cob, Number of kernels per row, Cob weight, Yield per plant, 100 grain weight and shelling percentage were recorded. Mean performance were calculated using the descriptive statistic analysis. Range was worked out for different biometrical traits from the minimum and maximum value of the trait.

\section{Results and Discussion}

Mean is the primary criterion for selection in any breeding programme. Mean serves as a basis for eliminating undesirable crosses or progenies. Choice of parents is one of the most essential step in any breeding programme. Selection method can extract good cultivars if the parents used in the breeding programme are suitable. Therefore, an elite inbred UMI 79 was selected to introgress SDM resistance from UMI 936(W). Inclusion of elite inbred as parent (UMI 79) will largely help to ensure the recovery of a high proportion of progenies (inbreds) with adaptation and quality that would in turn helpful in developing superior hybrids with SDM resistance.The parents selected in the study UMI 79 and UMI 936(w) was having extreme variations in case of SDM resistance parameters. $F_{1} s^{\prime}$ of these parents were selected for further advancement so that the recovery of the parental genotype is faster with not much compromise on local adaptability and per se performance of the recurrent inbred.

The important biometrical traits viz., days to 50per cent tasseling, days to 50per centsilking, days to maturity, plant height, ear height, cob length, cob diameter, number of rows per cob, number of grains per row, cob weight, shelling per cent, 100 grain weight and grain yield per plant were studied in the back crossed generations to simultaneously monitor the agronomic performance of the introgressed progenies. Mean values for various traits were computed for resistant progenies inBC $\mathrm{C}_{3} \mathrm{~F}_{1}$ generation. Among the progenies, UMI 79/936-C1-7-7-7 and UMI 79/936-C1-77-2 showed better per se performance for 
yield contributing characters. These two progenies showed highest mean values than the other progenies. The progeny UMI 79/936-C1-7-7-7 showed highest mean values for the characters namely cob length (15.56 $\mathrm{cm})$, cob diameter $(12.54 \mathrm{~cm})$, number of rows per cob (16.92), number of grains per row (17.85), cob weight (45.60g), 100 grain weight $(17.98 \mathrm{~g})$,yield per plant $(38.94 \mathrm{~g})$ and shelling per cent (71.97).In the case of progeny UMI 79/936-C1-7-7-2 also showed highest mean values for the characters namely cob length $(12.30 \mathrm{~cm})$, cob diameter $(11.17 \mathrm{~cm})$, number of rows per cob (16.44), number of grains per row (17.78), cob weight (43.69), 100 grain weight $(18.16 \mathrm{~g})$,yield per plant $(31.35 \mathrm{~g})$ and shelling per cent (71.33). The characters days to 50 per cent tasseling, days to 50 per cent silking and plant height for these progenies almost similar to recurrent parent.

For the progeny UMI 79/936-C1-7-7, days to 50 per cent tasseling value varied from 54 to 59 days with a mean of 55.68 days which was similar to the recurrent parent. Mean value for the trait days to 50 per cent silking was 57.68 days with range from 56 to 61 days. Plant height varied between a minimum of $68.00 \mathrm{~cm}$ and maximum of $122.00 \mathrm{~cm}$ with a mean of $94.84 \mathrm{~cm}$ and ear height ranged from $38.00 \mathrm{~cm}$ to $65.00 \mathrm{~cm}$ with a mean of $49.08 \mathrm{~cm}$. Cob weight and yield per plant ranged from 18.00 $\mathrm{gm}$ to $70.00 \mathrm{gm}$ and $10.20 \mathrm{gm}$ to $52.00 \mathrm{gm}$ respectively. Progeny UMI 79/936-C1-7-2, days to 50 per cent tasseling value varied from 54 to 60 days with a mean of 55.78 days. Mean value for the trait days to 50 per cent silking was 58 days with range from 56 to 62 days. Plant height varied between a minimum of $68.00 \mathrm{~cm}$ and maximum of $124.00 \mathrm{~cm}$ with a mean of $94.33 \mathrm{~cm}$ and ear height ranged from $34.00 \mathrm{~cm}$ to $66.00 \mathrm{~cm}$ with a mean of $48.78 \mathrm{~cm}$. Cob weight and yield per plant ranged from $18.00 \mathrm{gm}$ to $86.40 \mathrm{gm}$ and 10.20 $\mathrm{gm}$ to $60.00 \mathrm{gm}$ respectively. The mean value and the range of different biometrical traits for resistant progenies are presented in the Table 1 to Table 8. Similar results were obtained by Aarthi 2012, Vashishta et al., (2013), by Bekele and Rao (2014) and Panwar et al., (2013).

Table.1 Mean performance and range of progenies UMI79/936-C1 -3-2 and UMI79/936-C1 -3-4 in $\mathrm{BC}_{3} \mathrm{~F}_{1}$ generation for different biometrical traits

\begin{tabular}{|c|c|c|c|c|c|c|c|c|}
\hline \multirow[t]{3}{*}{ TRAITS } & \multicolumn{4}{|c|}{ Grand Mean } & Range & \multirow{2}{*}{\multicolumn{3}{|c|}{ Grand Mean Range }} \\
\hline & \multicolumn{2}{|c|}{ Parents } & \multicolumn{3}{|c|}{ UMI79/936-C1 -3-2 } & & & \\
\hline & P1 & $\mathbf{P 2}$ & $\mathbf{B C}_{3} \mathbf{F}_{1}$ & Min. & Max. & $\mathbf{B C}_{3} \mathbf{F}_{1}$ & Min. & Max. \\
\hline Days to 50 per cent tasseling & 55.40 & 57.40 & 56.08 & 54.00 & 58.00 & 56.83 & 54.00 & 60.00 \\
\hline Days to 50 per cent silking & 57.40 & 59.80 & 58.44 & 56.00 & 61.00 & 59.18 & 56.00 & 63.00 \\
\hline Plant height $(\mathrm{cm})$ & 84.00 & 102.00 & 83.54 & 68.00 & 104.00 & 89.84 & 60.00 & 116.00 \\
\hline Ear height $(\mathrm{cm})$ & 42.80 & 49.00 & 44.64 & 35.00 & 57.00 & 47.20 & 30.00 & 68.00 \\
\hline Cob length & 13.30 & 13.38 & 13.60 & 9.00 & 15.60 & 13.34 & 8.50 & 16.70 \\
\hline Cob diameter & 11.80 & 11.56 & 14.32 & 8.00 & 16.60 & 12.94 & 8.70 & 14.40 \\
\hline No.of.rows per cob $(\mathrm{cm})$ & 14.80 & 14.40 & 16.50 & 10.00 & 18.00 & 15.95 & 10.00 & 24.00 \\
\hline No.of.kernels per row $(\mathrm{cm})$ & 15.20 & 15.60 & 17.80 & 10.00 & 23.00 & 16.35 & 9.00 & 23.00 \\
\hline Cob weight $(\mathrm{g})$ & 35.53 & 30.82 & 39.80 & 20.00 & 60.28 & 40.39 & 12.00 & 78.00 \\
\hline Yield per plant (g) & 25.70 & 21.38 & 28.90 & 10.20 & 45.60 & 27.92 & 8.20 & 55.00 \\
\hline 100 Grain weight $(\mathrm{g})$ & 16.78 & 15.51 & 17.82 & 8.45 & 20.35 & 17.86 & 7.00 & 20.12 \\
\hline Shelling \% & 66.57 & 63.83 & 67.08 & 45.33 & 72.32 & 68.04 & 52.38 & 75.41 \\
\hline
\end{tabular}


Table.2 Mean performance and range of progenies UMI79/936-C1 -7-2 and UMI79/936-C1 -7-7 in $\mathrm{BC}_{3} \mathrm{~F}_{1}$ generation for different biometrical traits

\begin{tabular}{|c|c|c|c|c|c|c|}
\hline \multirow[t]{3}{*}{ TRAITS } & Grand Mean & \multicolumn{2}{|c|}{ Range } & Grand Mean & \multicolumn{2}{|c|}{ Range } \\
\hline & \multicolumn{3}{|c|}{ UMI79/936-C1 -7-2 } & \multicolumn{3}{|c|}{ UMI79/936-C1 -7-7 } \\
\hline & $\mathbf{B C}_{3} \mathbf{F}_{1}$ & Min. & Max. & $\mathbf{B C}_{3} \mathbf{F}_{1}$ & Min. & Max. \\
\hline Days to 50 per cent tasseling & 55.78 & 54.00 & 60.00 & 55.68 & 54.00 & 59.00 \\
\hline Days to 50 per cent silking & 58.00 & 56.00 & 62.00 & 57.68 & 56.00 & 61.00 \\
\hline Plant height $(\mathrm{cm})$ & 94.33 & 68.00 & 124.00 & 94.84 & 68.00 & 122.00 \\
\hline Ear height (cm) & 48.78 & 34.00 & 66.00 & 49.08 & 38.00 & 65.00 \\
\hline Cob length & 12.30 & 8.30 & 16.60 & 15.56 & 8.40 & 18.50 \\
\hline Cob diameter & 11.17 & 7.50 & 14.60 & 12.54 & 7.70 & 14.70 \\
\hline No.of.rows per cob (cm) & 16.44 & 12.00 & 22.00 & 16.92 & 10.00 & 20.00 \\
\hline No.of.kernels per row $(\mathrm{cm})$ & 17.78 & 7.00 & 29.00 & 17.85 & 7.00 & 25.00 \\
\hline Cob weight $(\mathrm{g})$ & 43.69 & 18.00 & 86.40 & 45.60 & 18.00 & 70.00 \\
\hline Yield per plant (g) & 31.35 & 10.20 & 60.00 & 38.94 & 10.20 & 52.00 \\
\hline 100 Grain weight (g) & 18.16 & 10.10 & 23.46 & 17.98 & 10.20 & 24.21 \\
\hline Shelling \% & 71.33 & 53.33 & 82.07 & 71.97 & 56.67 & 85.42 \\
\hline
\end{tabular}

Table.3 Mean performance and range of progenies UMI79/936-C1 -29-8 and UMI79/936-C1 29-9 in $\mathrm{BC}_{3} \mathrm{~F}_{1}$ generation for different biometrical traits

\begin{tabular}{|l|c|c|c|c|c|c|}
\hline \multirow{2}{*}{ TRAITS } & Grand Mean & \multicolumn{2}{|c|}{ Range } & \multicolumn{2}{c|}{ Grand Mean } & \multicolumn{2}{c|}{ Range } \\
\cline { 2 - 7 } & \multicolumn{2}{|c|}{ UMI79/936-C1 -29-8 } & \multicolumn{2}{c|}{ UMI79/936-C1 -29-9 } \\
\cline { 2 - 7 } & $\mathbf{B C}_{\mathbf{3}} \mathbf{F}_{\mathbf{1}}$ & $\mathbf{M i n}$. & $\mathbf{M a x}$. & $\mathbf{B C}_{\mathbf{3}} \mathbf{F}_{\mathbf{1}}$ & $\mathbf{M i n}$. & Max. \\
\hline Days to 50 per cent tasseling & 56.08 & 54.00 & 58.00 & 55.36 & 54.00 & 58.00 \\
\hline Days to 50 per cent silking & 58.75 & 56.00 & 61.00 & 57.36 & 56.00 & 60.00 \\
\hline Plant height $(\mathrm{cm})$ & 87.17 & 68.00 & 108.00 & 81.86 & 58.00 & 109.00 \\
\hline Ear height $(\mathrm{cm})$ & 44.33 & 35.00 & 55.00 & 44.68 & 34.00 & 58.00 \\
\hline Cob length & 13.27 & 9.60 & 15.80 & 12.49 & 9.00 & 16.00 \\
\hline Cob diameter & 11.44 & 7.90 & 14.70 & 11.22 & 8.20 & 15.00 \\
\hline No.of.rows per cob $(\mathrm{cm})$ & 15.50 & 10.00 & 20.00 & 15.82 & 10.00 & 22.00 \\
\hline No.of.kernels per row $(\mathrm{cm})$ & 16.67 & 10.00 & 22.00 & 16.41 & 10.00 & 22.00 \\
\hline Cob weight $(\mathrm{g})$ & 39.38 & 22.00 & 53.00 & 39.96 & 18.40 & 60.00 \\
\hline Yield per plant $(\mathrm{g})$ & 27.19 & 14.50 & 38.00 & 27.86 & 10.40 & 60.20 \\
\hline 100 Grain weight $(\mathrm{g})$ & 17.25 & 11.10 & 19.80 & 18.16 & 10.30 & 20.70 \\
\hline Shelling \% & 68.38 & 63.64 & 75.35 & 66.25 & 51.71 & 74.29 \\
\hline
\end{tabular}

Table.4 Mean performance and range of progenies UMI79/936-C1 -29-13 and UMI79/936-C1 - 
29-23 in $\mathrm{BC}_{3} \mathrm{~F}_{1}$ generation for different biometrical traits

\begin{tabular}{|l|c|c|c|c|c|c|}
\hline \multirow{2}{*}{ TRAITS } & Grand Mean & \multicolumn{2}{c|}{ Range } & \multicolumn{2}{c|}{ Grand Mean } & \multicolumn{2}{c|}{ Range } \\
\cline { 2 - 7 } & \multicolumn{2}{|c|}{ UMI79/936-C1 -29-13 } & \multicolumn{2}{c|}{ UMI79/936-C1 -29-23 } \\
\cline { 2 - 7 } & $\mathbf{B C}_{\mathbf{3}} \mathbf{F}_{\mathbf{1}}$ & $\mathbf{M i n}$. & $\mathbf{M a x}$. & $\mathbf{B C}_{\mathbf{3}} \mathbf{F}_{\mathbf{1}}$ & $\mathbf{M i n}$. & Max. \\
\hline Days to 50 per cent tasseling & 56.15 & 54.00 & 59.00 & 56.15 & 54.00 & 59.00 \\
\hline Days to 50 per cent silking & 58.45 & 56.00 & 61.00 & 58.45 & 56.00 & 61.00 \\
\hline Plant height (cm) & 82.15 & 60.00 & 108.00 & 82.15 & 60.00 & 108.00 \\
\hline Ear height $(\mathrm{cm})$ & 42.10 & 28.00 & 55.00 & 42.10 & 28.00 & 55.00 \\
\hline Cob length & 13.27 & 9.60 & 17.00 & 13.90 & 8.90 & 16.50 \\
\hline Cob diameter & 12.30 & 10.30 & 15.60 & 11.84 & 7.30 & 15.00 \\
\hline No.of.rows per cob $(\mathrm{cm})$ & 15.30 & 10.00 & 24.00 & 15.29 & 8.00 & 22.00 \\
\hline No.of.kernels per row $(\mathrm{cm})$ & 16.20 & 8.00 & 22.00 & 16.61 & 10.00 & 23.00 \\
\hline Cob weight $(\mathrm{g})$ & 36.61 & 16.80 & 66.20 & 38.49 & 15.20 & 66.50 \\
\hline Yield per plant $(\mathrm{g})$ & 24.14 & 9.40 & 51.40 & 26.20 & 8.20 & 45.00 \\
\hline 100 Grain weight $(\mathrm{g})$ & 17.65 & 11.10 & 20.50 & 16.98 & 8.20 & 19.00 \\
\hline Shelling \% & 67.40 & 50.00 & 72.64 & 68.60 & 49.54 & 71.60 \\
\hline
\end{tabular}

Table.5 Mean performance and range of progenies UMI79/936-C1 -29-35 and UMI79/936-C1 29-36 in $\mathrm{BC}_{3} \mathrm{~F}_{1}$ generation for different biometrical traits

\begin{tabular}{|c|c|c|c|c|c|c|}
\hline \multirow[t]{3}{*}{ TRAITS } & Grand Mean & \multicolumn{2}{|c|}{ Range } & Grand Mean & \multicolumn{2}{|c|}{ Range } \\
\hline & \multicolumn{3}{|c|}{ UMI79/936-C1 -29-35 } & \multicolumn{3}{|c|}{ UMI79/936-C1 -29-36 } \\
\hline & $\mathbf{B C}_{3} \mathbf{F}_{1}$ & Min. & Max. & $\mathbf{B C}_{3} \mathbf{F}_{1}$ & Min. & Max. \\
\hline Days to 50 per cent tasseling & 55.79 & 54.00 & 59.00 & 56.10 & 54.00 & 59.00 \\
\hline Days to 50 per cent silking & 57.96 & 56.00 & 61.00 & 58.31 & 56.00 & 61.00 \\
\hline Plant height $(\mathrm{cm})$ & 84.58 & 60.00 & 110.00 & 86.45 & 66.00 & 114.00 \\
\hline Ear height $(\mathrm{cm})$ & 43.50 & 28.00 & 56.00 & 45.97 & 36.00 & 58.00 \\
\hline Cob length & 13.28 & 10.00 & 16.00 & 13.02 & 8.80 & 16.00 \\
\hline Cob diameter & 12.70 & 9.20 & 15.00 & 11.59 & 8.20 & 15.00 \\
\hline No.of.rows per cob $(\mathrm{cm})$ & 18.25 & 12.00 & 22.00 & 15.72 & 10.00 & 22.00 \\
\hline No.of.kernels per row $(\mathrm{cm})$ & 18.00 & 12.00 & 24.00 & 16.59 & 10.00 & 23.00 \\
\hline Cob weight $(\mathrm{g})$ & 37.64 & 13.20 & 62.00 & 37.66 & 13.40 & 58.40 \\
\hline Yield per plant (g) & 27.27 & 10.20 & 60.20 & 26.70 & 7.80 & 48.30 \\
\hline 100 Grain weight (g) & 17.32 & 10.20 & 24.00 & 17.16 & 8.00 & 22.60 \\
\hline Shelling \% & 69.37 & 53.95 & 73.70 & 66.22 & 49.78 & 72.65 \\
\hline
\end{tabular}


Table.6 Mean performance and range of progenies UMI79/936-C1 -67-3 and UMI79/936-C1 67-12 in $\mathrm{BC}_{3} \mathrm{~F}_{1}$ generation for different biometrical traits

\begin{tabular}{|c|c|c|c|c|c|c|}
\hline \multirow[t]{3}{*}{ TRAITS } & Grand Mean & \multicolumn{2}{|c|}{ Range } & Grand Mean & \multicolumn{2}{|c|}{ Range } \\
\hline & \multicolumn{3}{|c|}{ UMI79/936-C1 -67-3 } & \multicolumn{3}{|c|}{ UMI79/936-C1 -67-12 } \\
\hline & $\mathbf{B C}_{3} \mathbf{F}_{1}$ & Min. & Max. & $\mathrm{BC}_{3} \mathbf{F}_{1}$ & Min. & Max. \\
\hline Days to 50 per cent tasseling & 56.00 & 54.00 & 59.00 & 56.16 & 54.00 & 59.00 \\
\hline Days to 50 per cent silking & 58.24 & 56.00 & 61.00 & 58.44 & 56.00 & 61.00 \\
\hline Plant height $(\mathrm{cm})$ & 83.71 & 60.00 & 112.00 & 87.77 & 62.00 & 112.00 \\
\hline Ear height $(\mathrm{cm})$ & 43.48 & 30.00 & 56.00 & 44.65 & 30.00 & 58.00 \\
\hline Cob length & 13.70 & 10.20 & 16.00 & 13.43 & 9.20 & 17.00 \\
\hline Cob diameter & 12.04 & 8.20 & 15.00 & 11.32 & 6.50 & 15.00 \\
\hline No.of.rows per cob (cm) & 14.48 & 10.00 & 22.00 & 15.31 & 8.00 & 22.00 \\
\hline No.of.kernels per row $(\mathrm{cm})$ & 16.19 & 10.00 & 23.00 & 16.73 & 9.00 & 24.00 \\
\hline Cob weight $(\mathrm{g})$ & 39.19 & 13.40 & 66.50 & 37.28 & 13.40 & 75.00 \\
\hline Yield per plant (g) & 27.99 & 7.80 & 51.60 & 26.45 & 7.80 & 56.00 \\
\hline 100 Grain weight (g) & 17.65 & 11.20 & 22.60 & 18.98 & 8.20 & 22.60 \\
\hline Shelling \% & 66.78 & 49.78 & 72.10 & 65.63 & 49.78 & 77.59 \\
\hline
\end{tabular}

Table.7 Mean performance and range of progenies UMI79/936-C1 -67-25 and UMI79/936-C1 101-12 in $\mathrm{BC}_{3} \mathrm{~F}_{1}$ generation for different biometrical traits

\begin{tabular}{|c|c|c|c|c|c|c|}
\hline \multirow[t]{3}{*}{ TRAITS } & Grand $\mathrm{I}$ & & ange & Grand $\mathrm{N}$ & & ange \\
\hline & \multicolumn{3}{|c|}{ UMI79/936-C1 -67-25 } & \multicolumn{3}{|c|}{ UMI79/936-C1 -101-12 } \\
\hline & $\mathrm{BC}_{3} \mathbf{F}_{1}$ & Min. & Max. & $\mathbf{B C}_{3} \mathbf{F}_{1}$ & Min. & Max. \\
\hline Days to 50 per cent tasseling & 55.83 & 54.00 & 59.00 & 55.92 & 54.00 & 59.00 \\
\hline Days to 50 per cent silking & 58.00 & 56.00 & 61.00 & 58.33 & 56.00 & 61.00 \\
\hline Plant height $(\mathrm{cm})$ & 86.91 & 66.00 & 114.00 & 80.31 & 68.00 & 108.00 \\
\hline Ear height $(\mathrm{cm})$ & 45.30 & 36.00 & 58.00 & 44.38 & 37.00 & 54.00 \\
\hline Cob length & 13.97 & 9.60 & 16.00 & 13.85 & 8.40 & 17.00 \\
\hline Cob diameter & 12.25 & 6.40 & 15.60 & 12.24 & 7.70 & 15.00 \\
\hline No.of.rows per cob $(\mathrm{cm})$ & 16.88 & 10.00 & 24.00 & 16.31 & 12.00 & 22.00 \\
\hline No.of.kernels per row $(\mathrm{cm})$ & 17.44 & 10.00 & 24.00 & 17.54 & 12.00 & 23.00 \\
\hline Cob weight $(\mathrm{g})$ & 39.30 & 17.80 & 62.00 & 41.38 & 18.00 & 65.00 \\
\hline Yield per plant (g) & 27.32 & 9.80 & 43.60 & 28.92 & 12.00 & 43.00 \\
\hline 100 Grain weight (g) & 17.90 & 11.60 & 23.00 & 18.32 & 11.24 & 22.30 \\
\hline Shelling \% & 67.74 & 49.54 & 76.19 & 69.49 & 59.09 & 72.14 \\
\hline
\end{tabular}


Table.8 Mean performance and range of progenies UMI79/936-C1 -101-13 and UMI79/936-C1 $-101-14$ in $\mathrm{BC}_{3} \mathrm{~F}_{1}$ generation for different biometrical traits

\begin{tabular}{|c|c|c|c|c|c|c|}
\hline \multirow[t]{3}{*}{ TRAITS } & Grand Mean & \multicolumn{2}{|c|}{ Range } & Grand Mean & \multicolumn{2}{|c|}{ Range } \\
\hline & \multicolumn{3}{|c|}{ UMI79/936-C1 -101-13 } & \multicolumn{3}{|c|}{ UMI79/936-C1 -101-14 } \\
\hline & $\mathrm{BC}_{3} \mathbf{F}_{1}$ & Min. & Max. & $\mathrm{BC}_{3} \mathbf{F}_{1}$ & Min. & Max. \\
\hline Days to 50 per cent tasseling & 56.67 & 55.00 & 58.00 & 56.67 & 55.00 & 58.00 \\
\hline Days to 50 per cent silking & 59.33 & 57.00 & 61.00 & 59.33 & 57.00 & 61.00 \\
\hline Plant height $(\mathrm{cm})$ & 84.67 & 68.00 & 98.00 & 84.67 & 68.00 & 98.00 \\
\hline Ear height (cm) & 45.33 & 38.00 & 52.00 & 45.33 & 38.00 & 52.00 \\
\hline Cob length & 15.73 & 14.50 & 16.70 & 13.94 & 10.30 & 16.00 \\
\hline Cob diameter & 13.13 & 12.20 & 14.00 & 12.39 & 8.50 & 15.00 \\
\hline No.of.rows per cob (cm) & 18.00 & 16.00 & 20.00 & 17.25 & 12.00 & 22.00 \\
\hline No.of.kernels per row $(\mathrm{cm})$ & 17.67 & 16.00 & 19.00 & 16.75 & 12.00 & 23.00 \\
\hline Cob weight $(\mathrm{g})$ & 42.47 & 34.00 & 52.00 & 43.58 & 15.60 & 62.00 \\
\hline Yield per plant (g) & 29.57 & 22.00 & 36.70 & 31.27 & 10.90 & 60.20 \\
\hline 100 Grain weight (g) & 19.40 & 17.10 & 22.10 & 17.71 & 14.00 & 23.00 \\
\hline Shelling \% & 69.25 & 64.71 & 72.46 & 68.44 & 53.95 & 77.42 \\
\hline
\end{tabular}

To conclude that the study revealed that among the sixteen progenies studied the progenies UMI 79/936-C1-7-7-7 and UMI 79/936-C1-7-7-2 showed better per se performance for yield contributing charactersviz.,days to 50 per cent tasseling, days to 50 per cent silking, days to maturity, plant height, ear height, cob length, cob diameter, number of rows per cob, number of grains per row, cob weight, shelling per cent, 100 grain weight and grain yield per plant. Hence, it's an indication that SDM resistant progenies posses the resistance to disease along with better agronomical performance.

\section{References}

Aarthi,P. 2012. Molecular marker assisted backcrossing for introgression of sorghum downy mildew resistance into elite inbred of maize (zea mays 1.)M.Sc (Ag.) Thesis submitted to the Tamil Nadu Agrl. University. Coimbatore. India.

Bekele, A. and T. N. Rao. 2014. Estimates of heritability, genetic advance and correlation study for yield and it's attributes in maize (Zea mays L.). J. of Plant Sci., 2(1): 1-4.

FAO (Food and Agricultural Organization).1992.

http//www.fao.org.

Jeffers, D., H. Cordova, S. Vasal, G. Srinivasan, D. Beck and M. Barandiaran. 2000. Status in breeding for resistance to maize diseases at CIMMYT. In: Vasal SK, Gonzalez Ceniceros F, Fan XM (Eds.). Proc. 7th Asian Regional Maize Workshop. PCARRD, Los Baos, Philippines, pp. 257-266.

Panwar, L. L., R. K. Mahawar and R. S. Narolia. 2013. Genetic variability and interrelationships among grain yield and yield components in maize. Annals of Plant and Soil Res., 15(1): 15-18.

Vashishta, A., N. N. Dixit, Dipika, S. K. Sharma and S. Marker. 2013. Studies on heritability and genetic advance estimates in Maize genotypes. Bioscience Discovery, 4(2): 165-168. 
How to cite this article:

Sumathi, K., K.N. Ganesan and Senthil, N. 2018. Estimation of Mean Performance in Sorghum Downy Mildew Resistant Back Cross Progenies $\left(\mathrm{BC}_{3} \mathrm{~F}_{1}\right)$ of Maize. Int.J.Curr.Microbiol.App.Sci. 7(06): 3855-3862. doi: https://doi.org/10.20546/ijcmas.2018.706.454 